Original research article

\title{
Quality of life in post-stroke patients
}

\author{
Lucia Dimunová ${ }^{1 *}$, Mária Sováriová Soósová ${ }^{1}$, Kinga Kardosová ${ }^{2}$, Martin Červený ${ }^{3}$, \\ Mária Belovičová ${ }^{4}$ \\ ${ }^{1}$ Pavol Jozef Šafárik University in Košice, Faculty of Medicine, Department of Nursing Care, Slovak Republic \\ ${ }^{2}$ Hospital with Out-patient Clinic of St. Barbora Rožňava, a. s, Neurological Department, Rožňava, Slovak Republic \\ ${ }^{3}$ University of South Bohemia in České Budèjovice, Faculty of Health and Social Sciences, Institute of Nursing, Midwifery and Emergency Care, \\ České Budějovice, Czech Republic \\ ${ }^{4}$ St. Elizabeth University of Health and Social Sciences Bratislava, n. o., Internal Outpatient Clinic Focusing on the Diagnosis and Treatment \\ of Liver Diseases, Remedium, s.r.o., Bardejovské Kúpele, Slovak Republic
}

\begin{abstract}
Introduction: Strokes are the third most common cause of hospitalization in Slovakia. This is a serious social and economic problem, because after a stroke almost half of the patients have a persistent neurological deficit. The goal of this research was to assess the quality of life of patients who have had an acute stroke.

Design: Quantitative cross-sectional study.

Methods: The Stroke Impact Scale (SIS 3.0) was completed by 80 patients, an average age of $69.9( \pm 9.49)$ years within 28 days after a stroke. The results were analyzed by the Mann-Whitney $U$ test and Spearman correlation.

Results: The average score for each SIS 3.0 domain ranged from 48.28 (social participation) to 75.18 (communication). The overall recovery rate was estimated at an average of $54.10( \pm 29.19)$ points. There were no significant differences in the SIS domains by gender, and a worse score in the memory and thinking domain was only identified in women $(p \leq 0.05)$. Older age significantly correlated with most domains $(p \leq 0.05)$. The association between overall recovery rate and all SIS domains $(p \leq 0.05)$, except the emotion domain, was confirmed. Conclusions: Assessing the consequences of strokes is important for the effective management of healthcare, psychological and social care, respecting the individual needs of the patient.
\end{abstract}

Keywords: Gender; Quality of life; Stroke; Stroke impact scale

\section{Introduction}

Strokes are the second most common cause of death and functional disability in the world, with the highest incidence in East Asia and Eastern European regions (Gorelick, 2019; Johnson et al., 2019). According to the Health Yearbook of the Slovak Republic 2018 (National Center for Health Information, 2019), strokes are the third most common cause of hospitalization of patients in Slovakia. Despite the increasing effectiveness of stroke management, the disease is a serious social and economic problem, as almost $50 \%$ of patients have a permanent neurological deficit after overcoming a stroke (Gdovinová, 2013; Gorelick, 2019; Szilasiová, 2011). The consequences of a stroke are extensive, affecting not only individuals, but also their families who are often unprepared or unable to cope with the process of rehabilitation and disability resulting from the disease (Fadrná and Školoudík, 2017; Ramos-Lima et al., 2018). The consequences include, in particular, motor disability, impaired self-care in activities of daily living (ADLs), speech disorders, changes in cognitive functions, and many other problems which often result in work impairment and disability. These consequences can significantly affect the quality of life of patients after a stroke (Šupínová and Sklenková, 2018).

Health-related quality of life (HRQoL) and subjective well-being are two indicators that are increasingly being integrated into health care assessment (Carod-Artal et al., 2008; Drugdová et al., 2020; Gurková, 2011; Lizáková et al., 2017; Tóthová et al., 2014). Several studies have addressed the assessment of quality of life in patients after a stroke in relation to secondary prevention and overall inclusion in life (Carod-Artal et al., 2008; Fadrná and Školoudík, 2017; Ramos-Lima et al., 2018). According to the Action Plan for Stroke in Europe 2018-2030 (Norrving et al., 2018), monitoring quality of life is one of the research and healthcare priorities for patients after a stroke. The economic impact of the effectiveness of stroke treatment is also at the center of attention (Drugdová et al., 2020). Evaluation of HRQoL after a stroke, especially motor and functional status, is important in the rehabilitation of patients. The measurement of psychological and social aspects of a patient's health and quality of life after a stroke is related to other therapeutic and nursing interventions.

\footnotetext{
* Corresponding author: Lucia Dimunová, Pavol Jozef Šafárik University in Košice, Faculty of Medicine, Department of Nursing Care, Trieda SNP 457/1, 04011 Košice, Slovak Republic; e-mail: lucia.dimunova@upjs.sk http://doi.org/10.32725/kont.2020.036 
The aim of this research study was to assess the quality of life related to health in patients who have had an acute stroke.

\section{Materials and methods}

The study had a descriptive cross-sectional character. It was performed in 80 hospitalized patients recovering from an acute stroke. Data collection was carried out from 1 July 2018 to 28 February 2019 in a medical facility at the neurology department in the Slovak Republic.

In accordance with the study by Duncan et al. (2002), we considered the acute phase after a stroke to be less than 28 days from diagnosis. Our study included hospitalized patients who met the following criteria: age of at least 18 or older, diagnosis of acute stroke established by a physician based on clinical symptoms and radiological findings on the brain confirmed by magnetic resonance or computed tomography, ischemic and haemorrhagic stroke. Patients excluded from the study were those who had: a transient ischemic attack, severe disability due to a previous neurological disorder, concomitant severe systemic disease, a reduced ability to understand the questionnaire (e.g. due to severe aphasia, dementia or decreased level of consciousness).

One of the specific tools for assessing HRQoL, which allows for a comprehensive multi-dimensional assessment of the consequences of a stroke, is the Stroke Impact Scale (SIS 3.0) developed by Duncan et al. (1999; 2002; 2003). It is a self-assessment tool assessing the impact of CMP in eight domains: strength (4 items), hand function (5 items), ADLs/ Instrumental ADLs (IADLs) (10 items), mobility (9 items), memory and thinking (7 items), emotions (9 items), communication (7 items) and social participation/roles' fulfilment (8 items). Each item is evaluated on a Likert scale from 1 to 5 , where a lower score means greater difficulties, and more serious consequences of CMP. For individual domains, the raw score is calculated by counting the values of the items making up the domain and the transformed score from 0 to 100 , where a higher score means a higher HRQoL. There are three items in the emotion domain ( $3 \mathrm{f}, 3 \mathrm{~h}$ and $\mathrm{Bi}$ ) that have different formulation polarities, so they need to be recoded. One item of the questionnaire focuses on the global perception of recovery experienced by patients and is scored from 0 to 100 , where a higher score means a higher recovery rate. The SIS 3.0 questionnaire is a reliable and valid tool for assessing the consequences of strokes, and it is also recommended by the neurological section of the American Association for Physical Therapy (Sullivan et al., 2013).

We verified the reliability of the questionnaire and its domains with a standardized coefficient $a$ according to Cronbach. All domains of the questionnaire have high reliability: strength 0.96; memory and thinking 0.97; emotions 0.78; communication 0.97; ADLs/IADLs 0.98; mobility 0.98; hand function 0.97; social participation 0.98 . The reliability of SIS 3.0 in our study was excellent, with a lower value in the emotion domain. Similar test reliability values have been found in other studies (Choi et al., 2017; Törnbom et al., 2017; Vellone et al., 2015) with the weakest Cronbach's alpha value for the emotion domain - 0.86 (Törnbom et al., 2017); 0.72 (Duncan et al., 2003).

Descriptive and inferential statistical methods were used in the statistical analysis. Correlations between age, overall recovery rate, and individual domains were assessed by the Spearman correlation coefficient $(r)$, and gender differences were assessed by the Mann-Whitney test. The results were processed at the alpha level $\leq 0.05$. SPSS statistical software, version 20 , was used for data analysis.

\section{Results}

The study group consisted of a total of 80 patients who have overcome a stroke, of which 44 were women (55\%) aged $70.2 \pm$ 9.96 years, and 36 were men ( $45 \%)$ aged $69.5 \pm 8.75$ years. The mean age of the patients was $69.9( \pm 9.49)$.

Table 1 shows the means and standard deviations of the individual HRQoL domains in the study group we monitored. For comparison, we present normative data from the original study by Duncan et al. (2002) performed in 287 patients with acute stroke with a mean age of 72.6 ( \pm 10.0 ) years. The overall recovery rate of our group of patients with acute stroke was rated on average at $54.10( \pm 29.19)$ points on a scale from 0 to 100 ( 0 - worst possible recovery rate, 100 - best possible recovery rate).

\begin{tabular}{|c|c|c|}
\hline Domains & $\mathrm{M} \pm \mathrm{SD}(n=80)$ & $\mathrm{M} \pm \mathrm{SD}$ \\
\hline Strength & $61.81 \pm 30.61$ & $67.33 \pm 31.09$ \\
\hline Memory and thinking & $73.61 \pm 27.00$ & $53.73 \pm 35.64$ \\
\hline Emotions & $57.78 \pm 18.38$ & $56.81 \pm 20.55$ \\
\hline Communications & $78.97 \pm 27.92$ & $72.08 \pm 35.47$ \\
\hline ADLs/IADLs & $61.39 \pm 37.92$ & $58.18 \pm 35.01$ \\
\hline Mobility & $58.33 \pm 43.40$ & $56.41 \pm 38.10$ \\
\hline Hand function & $58.06 \pm 40.78$ & $60.00 \pm 32.74$ \\
\hline Social participation & $50.69 \pm 37.04$ & $46.31 \pm 31.46$ \\
\hline
\end{tabular}

ADLs/IADLs - Activities of Daily Living/Instrumental Activities of Daily Living.

Individual HRQoL domains in patients with acute stoke were evaluated by gender (Table 2). We only found statistically significant differences in the domain of memory and thinking, with worse score in women.

The overall recovery rate was negatively correlated with age $(r=-0.332 ; p<0.01)$, which means the recovery rate deteriorated with age. The correlations between age, overall recovery rate and SIS 3.0 domains are shown in Table 3. The results show that older age was associated with poorer recovery rates in the area of strength (affected limb), poorer quality of memory and thinking, ADLs and IADLs, mobility, hand function, and the rate of social participation is also deteriorating. In this group, older age was associated with a higher incidence of positive emotions. No significant association was confirmed between age and communication. The study confirmed the association between the overall recovery rate and all SIS 3.0 domains except the emotion domain.

\section{Discussion}

Strokes are not only associated with numerous physical consequences, but also mental and social consequences - and this necessitates a comprehensive assessment. The aim of this study was to assess the health-related quality of life in patients with acute stroke by the self-assessment tool SIS 3.0. 
Table 2. Gender differences in SIS 3.0 domains $(n=80)$

\begin{tabular}{llcc} 
Domains & M SD men & M \pm SD women & $p$-value \\
\hline Strength & $61.81 \pm 30.61$ & $67.33 \pm 31.09$ & 0.354 \\
\hline Memory and thinking & $73.61 \pm 27.00$ & $53.73 \pm 35.64$ & 0.023 \\
\hline Emotions & $57.78 \pm 18.38$ & $56.81 \pm 20.55$ & 0.828 \\
Communications & $78.97 \pm 27.92$ & $72.08 \pm 35.47$ & 0.652 \\
\hline ADLs/IADLs & $61.39 \pm 37.92$ & $58.18 \pm 35.01$ & 0.586 \\
\hline Mobility & $58.33 \pm 43.40$ & $53.41 \pm 38.10$ & 0.359 \\
Hand function & $58.06 \pm 40.78$ & $60.00 \pm 32.74$ & 0.907 \\
\hline Social participation & $50.69 \pm 37.04$ & $46.31 \pm 31.46$ & 0.907 \\
\hline ADLs/IADLs - Activities of Daily Living/Instrumental Activities of Daily Living. & & \\
\hline
\end{tabular}

Table 3. Spearman's correlation between age, overall recovery rate, and SIS $\mathbf{3 . 0}$ domains

\begin{tabular}{lcc} 
Domains & Age & Overall recovery rate \\
\hline Strength & $-0.215^{*}$ & $0.817^{* * *}$ \\
\hline Memory and thinking & $-0.311^{* *}$ & $0.828^{* * *}$ \\
Emotions & $0.316^{* *}$ & -0.168 \\
\hline Communications & -0.162 & $0.664^{* * *}$ \\
\hline ADLs/IADLs & $-0.432^{* * *}$ & $0.929^{* * *}$ \\
\hline Mobility & $-0.481^{* * *}$ & $0.922^{* * *}$ \\
\hline Hand function & $-0.350^{* * *}$ & $0.901^{* * *}$ \\
\hline Social participation & $-0.382^{* * *}$ & $0.864^{* * *}$ \\
\hline
\end{tabular}

ADLs/IADLs - Activities of Daily Living/Instrumental Activities of Daily Living.

${ }^{*} p \leq 0.05 ;{ }^{* *} p<0.01,{ }^{* * *} p<0.001$.

A descriptive analysis of the questionnaire showed that patients with acute stroke achieved the worst results in the domain of social participation, as well as in the area of overall mobility, hand function and performance of normal and instrumental daily activities. The areas of physical strength and mobility, limitation of manual dexterity, and activities of daily living were also rated lowest by the patients in the study of Duncan et al. (2002), Jenkinson et al. (2013), Šupínová and Sklenková (2018) and Vellone et al. (2015). Similarly, in a Korean study conducted in 70 patients overcoming a stroke with subacute and chronic form (mean age 54.97 years; men $65 \%$ ), Choi et al. (2017) found the worst scores in the domains of strength, hand function, social participation, and ADLs/ IADLs.

In a Swedish study by Törnbom et al. (2017) conducted in 104 patients within 1 month of a stroke (mean age 68 years; men 57\%), patients achieved the worst scores in the domain of hand function, social participation, strength, and ADLs/ IADLs. Consistent with our results, the authors of the above mentioned Swedish study identified the following specific items as the worst rated by patients: tying shoelaces, opening a bottle or cup, turning a handle, lifting heavy objects, ability to manage one's life, ability to work, social activities, ability to help others, lifting heavy objects, active leisure.

Similar to the studies of Choi et al. (2017), Jenkinson et al. (2013), Törnbom et al. (2017) a Vellone et al. (2015), we recorded the best score in the domain of communication.

When assessing the quality of life and for the whole process of care, it is important to know that the following char- acteristics especially predict a worse quality of life: older age, female gender, haemorrhagic strokes and the type of coping strategy (Solgajová et al., 2017). In connection with older age, a negative association with most domains was confirmed in our respondents, similarly to the study of Kamel et al. (2010). The conclusions of the research of Supínová and Sklenková (2018) confirmed that the quality of life - as well as the overall recovery rate of patients after a stroke - are reduced, but they are not affected by the age or sex of patients. Only the evaluation of selected areas of patients' lives are related to age. In our study, we did not notice significant differences between the sexes; except for in the domain of memory and thinking, where there was a worse score in women. The studies of Al-Qazzaz et al. (2014) and Chen et al. (2015) draw attention to the issue of detection of memory impairments and support of cognitive functions in patients after a stroke.

In line with increasing the quality of health care, the need for individualized, patient-oriented care is also mentioned. Individualized care focuses on the individual and his or her specific health problems, respects the individual preferences, needs and values of the patient and follows these when choosing clinical decisions (Suhonen et al., 2009; Wolfe, 2001). The SIS tool enables a comprehensive assessment of the consequences of a stroke from the patient's perspective. The obtained results can be helpful in selecting appropriate interventions and planning current and subsequent health care (medical, nursing, rehabilitation), psychological and social care respecting the individual needs of the patient, as well as in testing the effectiveness of interventions used in the therapy of patients with a stroke.

It is important to ensure continuous health and social care in patients after a stroke. After hospital discharge, patients can be placed in a home environment (and care is provided by home nursing care agencies), long-term care wards, physiotherapy and rehabilitation departments, the Nursing Home or the Facility for elderly people, or, during the convalescence period they can undergo spa treatment. The rehabilitation program, meeting basic biological needs, return to the patient's self-self-care, practice and consolidation of cognitive functions, and educational activity of the nurse remain at the center of care attention. Cooperation with the patient's family in psychological and social support is irreplaceable. The authors of the guidelines "Action Plan for Strokes in Europe 2018-2030" state that it is necessary to focus on secondary and tertiary prevention after the end of the acute stage of a stroke, and in particular on four overlapping categories: health problems, problems with physical activity, well-being, awareness and support (Norrving et al., 2018).

This study also has limitations, which relate in particular to the size and selection of the research sample and the cross-sec- 
tional design. In the future, it would be appropriate to test SIS 3.0 tool in patients with sub-acute and chronic forms of stroke, to extend research to analyze the impact of socio-demographic and clinical factors (type and severity of stroke, multi-morbidity) on the consequences of stroke and health-related quality of life.

\section{Conclusions}

A stroke brings many consequences, not only in the form of physical disability, but also in relation to emotional, cognitive and social impairment. The SIS 3.0 questionnaire allows for a holistic assessment of the impact of the disease on health and quality of life from the patient's perspective. The obtained results, especially in the initial phase of a stroke, can be helpful in intervention planning within comprehensive multidisciplinary care - in which physicians, nurses, physiotherapists, psychologists, speech therapists, nutritional therapists, carers and social workers are actively involved, respecting patient's individual needs.

\section{Ethical considerations}

The authors declare that the research was carried out in accordance with the Declaration of Helsinki of 1964 and its last revision of 2013. Data collection was carried out with the consent of the management of the medical facility concerned (Decision No. 262-002 / 2018-OŠE). All patients enrolled in the study were informed of the aims and intentions of the study, that their participation was voluntary and anonymous, that there were no risks associated with participating in the study, and that they may cancel their participation at any time without any reason.

\section{Conflict of interests}

The authors have no conflict of interests to declare.

\section{Kvalita života pacientov po cievnej mozgovej príhode}

Súhrn

Úvod: Cievna mozgová príhoda je tretou najčastejšou príčinou hospitalizácie pacientov na Slovensku. Predstavuje vážny sociálny a ekonomický problém, pretože u takmer polovice pacientov ostáva po prekonaní tohto stavu trvalý neurologický deficit.

Dizajn: Kvantitatívna prierezová štúdia.

Ciel: Ciel'om výskumu bolo posúdit' kvalitu života u pacientov v akútnom štádiu po cievnej mozgovej príhode.

Metodika: Dotazník Stroke Impact Scale (SIS 3.0, Škála vplyvu mŕtvice) vyplnilo 80 pacientov s priemerným vekom 69,9 ( \pm 9,49) rokov v období do 28 dní po CMP. Výsledky boli analyzované Mann-Whitneyho U testom a Spearmanovou koreláciou.

Výsledky: Priemerné skóre sa v jednotlivých doménach SIS 3.0 pohybovalo od 48,28 (sociálna participácia) po 75,18 (komunikácia) bodov. Celková miera zotavenia bola hodnotená priemerne $54,10( \pm 29,19)$ bodmi. Podl'a pohlavia neboli zistené signifikantné rozdiely $\mathrm{v}$ doménach SIS, iba v doméne pamäte a myslenie dosiahli horšie skóre ženy $(p \leq 0,05)$. Vyšší vek signifikantne negatívne koreloval $s$ väčšinou domén $(p \leq 0,05)$. Potvrdila sa asociácia medzi celkovou mierou zotavenia a všetkými doménami SIS $(p \leq 0,05)$, okrem domény emócií.

Záver: Hodnotenie následkov cievnej mozgovej príhody je dôležité pre efektívny manažment zdravotnej, psychologickej a sociálnej starostlivosti rešpektujúc individuálne potreby pacienta.

Kl'účové slová: cievna mozgová príhoda; kvalita života; pohlavie; škála vplyvu mŕtvice

\section{References}

1. Al-Qazzaz NK, Ali SH, Ahmad SA, Islam S, Mohamad K (2014). Cognitive impairment and memory dysfunction after a stroke diagnosis: a post memory assessment. Neuropsychiatr Dis Treat 10: 1677-1691. DOI: 10.2147/NDT.S67184.

2. Carod-Artal FJ, Coral LF, Trizotto DS, Moreira CM (2008). The Stroke Impact Scale 3.0: evaluation of acceptability, reliability, and validity of the Brazilian version. Stroke 39(9): 2477-2484. DOI: 10.1161/STROKEAHA.107.513671.

3. Chen CHX, Mao RH, Li AX, Zhao YN, Zhang M (2015). Effect of visual training on cognitive function in stroke patients. IJNS 2(4): 329-333. DOI: 10.1016/j.ijnss.2015.11.002.13.

4. Choi SU, Lee HS, Shin JH, Ho SH, Koo MJ, Park KH, et al. (2017). Stroke Impact Scale 3.0: Reliability and Validity Evaluation of the Korean Version. Ann Rehabil Med 41(3): 387-393. DOI: 10.5535/arm.2017.41.3.387.

5. Drugdová I, Rogalewicz V, Šrámek M, Kopalová V, Krahula O, Gavurová B, et al. (2020). Health-related quality of life measures for a cost-effectiveness analysis of ischemic stroke therapies. Kontakt 22(2): 128-136. DOI: 10.32725/kont.2020.019.

6. Duncan PW, Bode RK, Min Lai S, Perera S (2003). Rasch analysis of a new stroke-specific outcome scale: The Stroke Impact Scale. Arch Phys Med Rehabil 84(7): 950-963. DOI: 10.1016/s00039993(03)00035-2.
7. Duncan PW, Lai SM, Tyler D, Perera S, Reker DM, Studenski S (2002). Evaluation of proxy responses to the Stroke Impact Scale. Stroke 33(11): 2593-2599. DOI: 10.1161/01. str.0000034395.06874.3e.

8. Duncan PW, Wallace D, Lai SM, Johnson D, Embretson S, Laster LJ (1999). The Stroke Impact Scale Version 2.0: Evaluation of reliability, validity and sensitivity to change. Stroke 30(10): 2131-2140. DOI: 10.1161/01.str.30.10.2131.

9. Fadrná T, Školoudík D (2017). Kvalita života u soběstačných pacientů po cévní mozkové příhodě. [Quality of life in selfsuffient patients after stroke]. Cesk Slov Neurol 113(3): 323-327. DOI: 10.14735/amcsnn2017csnn.eul.

10. Gdovinová Z (2013). Manažment cievnej mozgovej príhody vo svetle súčasných odporúčaní. [Stroke management in the light of current guidelines]. Interná med 13(10): 441-444.

11. Gorelick PH (2019). The global burden of stroke: persistent and disabling. Lancet Neurol 18(5): 417-418. DOI: 10.1016/S14744422(19)30030-4.

12. Gurková E (2011). Hodnocení kvality života. Pro klinickou praxi a ošetřovatelský výzkum. [Evaluation of quality of life. For clinical practice and nursing research]. Praha: Grada Publishing, $224 \mathrm{p}$.

13. Jenkinson C, Fitzpatrick R, Crocker H, Peters M (2013). The Stroke Impact Scale: validation in a UK setting and development of a SIS short form and SIS index. Stroke 44(9): 2532-2535. DOI: 10.1161/STROKEAHA.113.001847. 
14. Johnson CO, Nguyen M., Roth GA, Nichols E, Alam T, Abade D, et al. (2019). Global, regional, and national burden of stroke, 1990-2016: a systematic analysis for the Global Burden of Disease Study 2016. Lancet Neurol 18(5): 439-458. DOI: 10.1016/S1474-4422(19)30034-1.

15. Kamel A, Ghani A, Zaiton MA, El-Motayam AS, El-Fattah DA (2010). Health related quality of life in stroke survivors measured by the Stroke Impact Scale. Egypt J Neurol Psychiat Neurosur 47(2): 267-274.

16. Lizáková L, Mrosková $S$, Novotná $Z$, Horanská V, Filičková $M$ (2017). The quality of life of dialysis patients in the context of nursing. Aktuality v nefrologii 23(3): 139-144.

17. Národné centrum zdravotníckych informácií (2019). Zdravotnícka ročenka Slovenskej republiky 2018. [National Health Information Center in Slovakia]. [online] [cit. 201912-04]. Available from: http://www.nczisk.sk/Documents/ rocenky/2018/Zdravotnicka_rocenka_Slovenskej_ republiky_2018.pdf.

18. Norrving B, Barrick J, Davalos A, Dichgans $\mathrm{M}$, Cordonnier $\mathrm{CH}$ Guekht A, et al. (2018). Action Plan for Stroke in Europe 2018-2030. Eur Stroke J 3(4): 309-336. DOI: 10.1177/2396987318808719.

19. Ramos-Lima MJM, Brasileiro IC, Lima TL, Braga-Neto P (2018). Quality of life after stroke: impact of clinical and sociodemographic factors. Clinics (Sao Paulo) 73: e418. DOI: $10.6061 /$ clinics/2017/e418.

20. Solgajová A, Vörösová G, Zrubcová D (2017). Determinants of quality of life in patients after stroke. Ošetrovatel'stvo: teória, výskum, vzdelávanie 1(1): 34-39.

21. Suhonen R, Välimäki M., Leino-Kilpi H (2009). The driving and restraining forces that promote and impede the implementation of individualised nursing care: a literature review. Int J Nurs Stud 46(12): 1637-1649. DOI: 10.1016/j. ijnurstu.2009.05.012.

22. Sullivan JE, Crowner BE, Kluding PM, Nichols D, Rose DK, Yoshida R, et al. (2013). Outcome measures for individuals with stroke: Process and recommendations from the American Physical Therapy Association neurology section task force. Phys Ther 93(10): 1383-1396. DOI: 10.2522/ptj.20120492.

23. Šupínová M, Sklenková G (2018). The quality of life of patients after an acute stroke. Kontakt 20(2): e153-159. DOI: 10.1016/j. kontakt.2018.02.001.

24. Szilasiová J (2011). Vybrané kapitoly zo špeciálnej neurológie pre študentov zubného lekárstva. [Select chapters from special neurology for students of dental medicine]. Košice: Univerzita Pavla Jozefa Šafárika v Košiciach, 234 p.

25. Tóthová V, Bártlová S, Dolák F, Kaas J, Kimmer D, Maňhalová J, et al. (2014). Quality of life in patients with chronic diseases. Neuro Endocrinol Lett 35(Suppl. 1): 11-18.

26. Törnbom K, Persson HC, Lundälv J, Sunnerhagen KS (2017). Self-Assessed Physical, Cognitive, and Emotional Impact of Stroke at 1 Month: The Importance of Stroke Severity and Participation. J Stroke Cerebrovasc Dis 26(1): 57-63. DOI: 10.1016/j.jstrokecerebrovasdis.2016.08.029.

27. Vellone E, Savini S, Fida R, Dickson VV, Melkus GD, CarodArtal FJ, et al. (2015). Psychometric evaluation of the Stroke Impact Scale 3.0. J Cardiovasc Nurs 30(3): 229-241. DOI: $10.1097 / J C N .0000000000000145$.

28. Wolfe A (2001). Institute of Medicine Report: Crossing the Quality Chasm: A New Health System for the 21st Century. PPNP 2(3): 233-235. DOI: 10.1177/152715440100200312. 